\title{
ON THE AGCUMULATION AND SEASONAL STRATIFICATION OF SNOW AT THE SOUTH POLE
}

\author{
By Anthony J. Gow \\ (U.S. Army Cold Regions Research and Engineering Laboratory, Hanover, New Hampshire, \\ U.S.A.)
}

\begin{abstract}
The seasonal distribution of snow at the South Pole and its relationship to stratigraphy was investigated in pits dug beside a number of four-year-old accumulation stakes. Results show that conventional stratigraphic methods yield thoroughly reliable values of accumulation rates. Even hiatuses in accumulation can be identified from the intensity of sublimation of layers of depth hoar in the stratigraphic section. Such hiatuses are due almost invariably to the prolonged absence of accumulation rather than to widespread scouring of pre-existing layers of snow. The bulk of the year's accumulation is deposited as dunes during winter. The majority of dunes are subsequently transformed into linear sastrugi by wind with the result that the amplitude of surface relief observed at the end of winter frequently exceeds the average thickness of snow accumulated annually. Such gross relief does not persist to the end of summer, however. Instead the dunes and sastrugi are gradually worn down by a process of sublimation-deflation. It is this leveling of the surface relief in summer and the resultant redistribution of snow more uniformly over the surface that are believed to be the significant factors in the formation of the systematic stratigraphy observed in pits at the South Pole.
\end{abstract}

RÉsumÉ. Sur l'accumulation et la stratification saisonnière de la neige au Póle Sud. La distribution saisonnière de la neige au Pôle Sud et sa relation avec la stratigraphie ont été étudiées dans des puits creusés a côté d'un certain nombre de balises d'accumulation agées de quatre ans. Les résultats montrent que les méthodes stratigraphiques conventionnelles donnent complétement de bonnes valeurs de l'accumulation. Même des hiatus dans l'accumulation peuvent être identifiés de l'intensité de la sublimation des strates de givre de profondeur dans la section stratigraphique étudiée. De tels hiatus sont presque invariablement dus à l'absence prolongée d'accumulation plus qu'à une large disparition de strates de neige pré-existantes. La masse de l'accumulation annuelle est déposée en hiver sous forme de dunes. La majorité des dunes sont par conséquent transformées en sastrugis linéaires par le vent avec le résultat que l'amplitude du relief superficiel observée à la fin de l'hiver dépasse souvent l'épaisseur moyenne de la neige que s'accumule annuellement. Cependant de tels reliefs ne subsistent pas jusqu'à la fin de l'été. Ainsi, les dunes et sastrugis sont graduellement usés par un processus de sublimation-déflation. C'est ce nivellement du relief superficiel et la redistribution résultante de la neige plus uniformément sur la surface qui semblent être les facteurs déterminants de la formation de la stratigraphie systématique observée dans les puits du Pôle Sud.

Zusammenfassung. Über den Auftrag und die jahreszeitliche Schichtung des Schnees am Südpol. Die jahreszeitliche Verteilung des Schnees am Südpol und ihre Beziehung zur Stratigraphie wurde in Schächten untersucht, die neben einer Anzahl von 4 Jahre alten Pegelstangen gegraben wurden. Die Ergebnisse zeigen, dass die üblichen stratigraphischen Methoden zu durchaus zuverlässigen Werten des Auftragganges führen. Selbst Lücken im Auftrag können aus dem Mass der Sublimierung von Schichten des Tiefenreifs (depth hoar) im stratigraphischen Profil festgestellt werden. Solche Lücken sind fast durchwegs eher auf längeres Ausbleiben von Schneefall als auf grossflächiges Fortblasen von vorher abgelagerten Schneeschichten zurückzuführen. Die Hauptmasse des Jahresauftrags wird in Form von Dünen wahrend des Winters abgelagert. Die meisten Dünen werden in der Folge durch den Wind in lineare Sastrugi umgeformt, mit dem Ergebnis, dass am Ende des Winters die Amplitude des Oberflächenreliefs häufig die mittlere Mächtigkeit des jährlich abgelagerten Schnees übertrifft. Dieses grobe Relief bleibt jedoch nicht bis zum Ende des Sommers erhalten. Vielmehr werden die Dünen und Sastrugi allmählich durch einen Prozess der Sublimierung und Entleerung abgetragen. Auf diese Einebnung des Oberflächenreliefs im Sommer und die damit verbundene gleichmässigere Verteilung des Schnees über die Oberfläche dürfte vor allem die systematische Stratigraphie zurückzuführen sein, die in den Schächten am Südpol beobachtet wurde.

\section{INTRODUCTION}

During studies of the age hardening of snow at the South Pole in December r96o (Gow and Ramseier, I963), a three-meter pit was dug to collect samples of naturally compacted snow. It was somewhat surprising at the time to observe a relatively uniform and systematic stratigraphy in the pit wall since with the relatively low rate of accumulation $(20 \mathrm{~cm}$. snow per year) and occurrence of some high sastrugi in the immediate vicinity of the pit, rather irregular layering might have been expected. Particularly rough surface relief with sastrugi up to $40 \mathrm{~cm}$. high is to be observed at the end of winter at the South Pole. However, a very considerable reduction of this surface relief was observed to take place during the summer and by mid-January even the largest sastrugi had been substantially leveled. The implication here 
is that it is this widespread leveling of the surface relief during summer that is primarily responsible for the formation of uniform stratigraphy in the walls of snow pits. A more thorough investigation of the above features was accomplished the following summer and it is the purpose of this paper to present the major results of these studies.

Specifically, these studies of the accumulation and stratification of snow at the South Pole were concerned with: (I) investigations of the criteria of annual layering, including pit studies at a number of accumulation stakes to determine just how precisely the pit stratigraphy could be correlated with actual measurements of accumulation at these stakes, and (2) qualitative observations of changes of the snow surface, particularly in regard to the distribution of snow dunes and old wind-polished surfaces, and the sublimation and deflation of dunes and linear sastrugi (eroded snow dunes) during the summer.

\section{Pit Studies}

Summer and winter weather conditions and sun radiation conditions at the South Pole are sufficiently contrasted to permit seasonal stratification to develop in the snow cover. This fact was appreciated first by Giovinetto (1960) who by carefully analyzing cyclical changes in the snow stratigraphy was able to date the snow to a depth of $26 \mathrm{~m}$. (r $9^{8} \mathrm{yr}$. of accumulation) in a snow mine at the South Pole. Particularly useful in this respect were the seasonal boundary layers within the annual strata, i.e. the spring and autumn transition layers. These, of course, correspond to times of most rapid temperature changes when temperature gradients in the snow are steepest and when layers of sublimation crystals are most likely to form. The fall period seems to offer the greatest opportunity for the formation of depth hoar. In this regard the stratigraphy observed in pits at the South Pole is no different from that observed in other parts of Antarctica where delineation of annual layering hinges essentially on the identification of fall surfaces and their associated layers of depth hoar. In fact, it turns out for a number of reasons that snow stratigraphy at the South Pole is much simpler to interpret than is generally imagined.

The essential stratigraphic relationships can be demonstrated here with the profile obtained from a $2.5 \mathrm{~m}$. pit located about $\mathrm{I} 50 \mathrm{~m}$. up-wind from the aurora observation tower (Fig. I). Excavated by the station meteorologists during December i 96 r for installing an undersnow instrument recording hut, this pit measured $5 \mathrm{~m}$. square and thus provided ample opportunity for observing lateral variations of snow stratification. The stratigraphy was sharply preserved and there was a significant absence of gross unevenness in the snow layers. This uniformity of layering was perhaps the most surprising feature of the snow stratigraphy in this pit. Minor irregularities do exist (variations of up to $15 \mathrm{~cm}$. in layer thickness were observed occasionally) but these were always much more subdued than the surrounding snow surface with dunes and sastrugi as high as $40 \mathrm{~cm}$. The stratigraphic sequence consisted essentially of layers of depth hoar alternating with relatively fine-grained strata, the latter being up to ten times as thick as the layers of depth hoar. The layers of depth hoar were rarely thicker than $2 \mathrm{~cm}$. and were composed of loosely aggregated grains and crystals. A vertical structure of crystals, indicative of the principal direction of vapor migration during sublimation was readily discernible in most depth-hoar layers. These were invariably overlain by an iced crust (up to $0.5 \mathrm{~mm}$. thick) and sometimes the bottom of a layer of depth hoar was also crusted. The relatively fine-grained layers usually became coarser toward the contact with the overlying depth hoar. This coarsening of grain can most probably be attributed to metamorphism of the surface snow layers during the summer. A general increase in grain size with depth in the pit was also observed. Thus, while the effects of sublimation tend to be concentrated in the layers of depth hoar, there is with time a slow but definite grain growth in the snow pack. Annual layering in this pit (see Figure I for the indicated accumulation) was provisionally identified on the basis of depth-hoar occurrence, it being assumed that just a single layer of 
depth hoar is formed each year. For the interval $195^{2-57}$ the snow in this pit accumulated at an average rate of $7.4 \mathrm{~cm}$. water equivalent per year, in close agreement with the pit measurements of Giovinetto (1960). However, since 1957 the accumulation appears to have increased on the average to about $10 \mathrm{~cm}$. water equivalent per year. Measurements at a

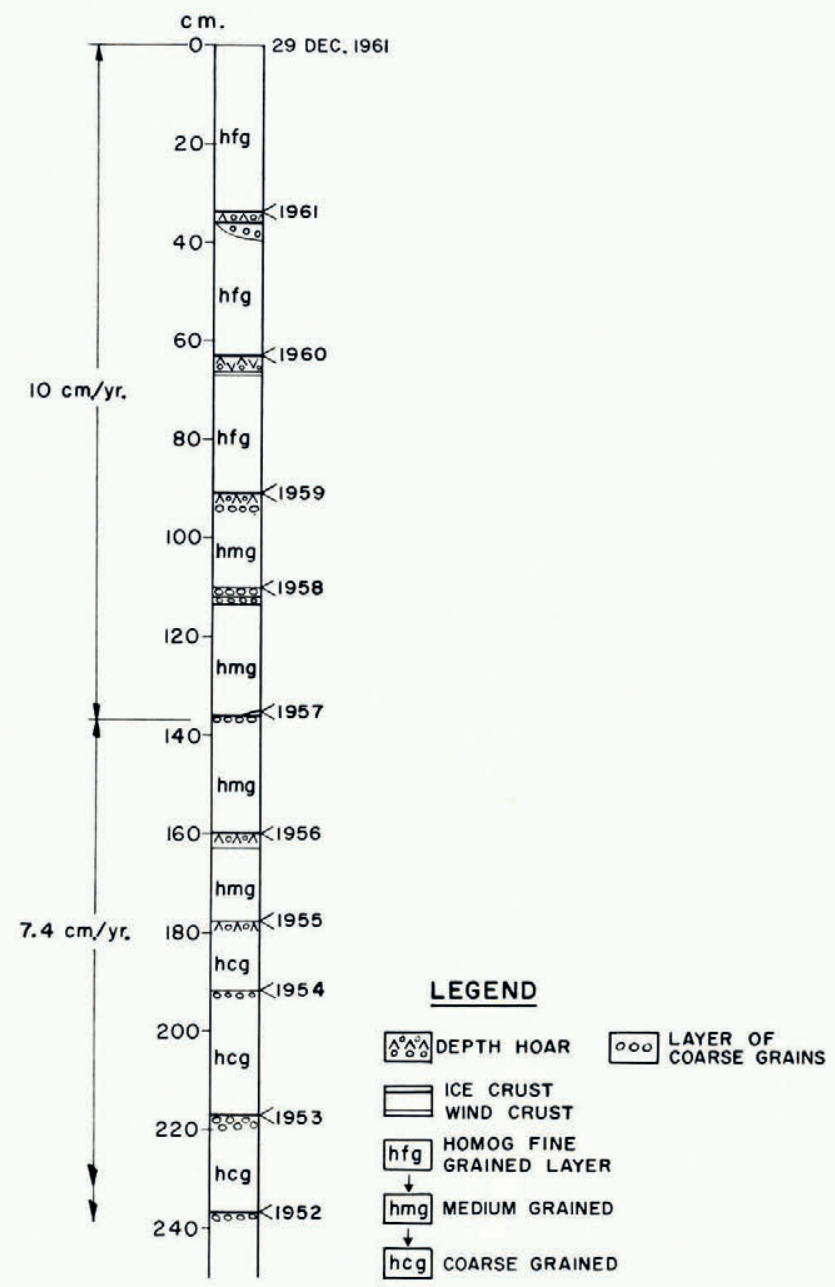

Fig. I. Snow stratigraphy in a pit excavated by the meteorologists during December 196r. The tick marks and associated dates refer to the late summer surfaces as interpreted from the slratigraphy. The South Pole station was first occupied in January 1957 and the indicated accumulation rates $(\mathrm{cm}$. water equivalent per year) relate to the five-year averages before and after this date

large number of accumulation stakes since January 1958 have revealed an almost constant rate of accumulation of $7 \cdot 0 \mathrm{~cm}$. water equivalent per year, i.e. about the same as observed in the pit from 1952 to 1957 . This apparent surplus in the pit can be attributed most likely to the influence of the station itself. As already noted, this pit was located less than $150 \mathrm{~m}$. from the aurora building which was erected in December $195^{6}$ during the construction of the South Pole station. However, it was also noted that the layers of depth hoar at $63-66 \mathrm{~cm}$. and $9 \mathrm{I}-95$ $\mathrm{cm}$. were appreciably thicker and more heavily crusted than usual. These unusually thick 
layers of depth hoar clearly indicate either exceptionally severe or prolonged sublimation or they could reflect hiatuses in accumulation, i.e. two layers of depth hoar formed approximately a year apart would tend to merge into a single layer if little or no accumulation occurred in the intervening period. These could prove difficult to identify in a pit. Years missed in this way would cause the average accumulation to be overestimated. On the other hand, the formation of two distinctive layers of depth hoar in a single accumulation year could be confused with two years' accumulation. Perhaps the simplest way of testing these and other critical aspects of seasonal stratification is to examine the stratigraphy in a pit dug beside a stake where accumulation had been measured for several years.

\section{Stake-Pit Correlation Studies}

On 29 December 1961 snow pits were dug beside five accumulation stakes in the fouryear-old farm at the South Pole. This stake field was established by M. Giovinetto on 27 January 1958, and four years' measurements at 36 bamboo poles have yielded the following data:

I. The yearly average accumulation has remained almost constant at about $7 \cdot 0 \mathrm{~g} . \mathrm{cm} .^{-2}$ yr. ${ }^{-1}(19-20 \mathrm{~cm}$. of snow).

2. The maximum accumulation recorded at any one stake in any one year was $53 \mathrm{~cm}$. snow.

3. The minimum accumulation amounted to minus $2 \mathrm{~cm}$. snow.

4. Not more than $102 \mathrm{~cm}$. snow and not less than $5^{8 \mathrm{~cm}}$. snow was recorded at any stake in four years of accumulation. The measurements also bring out the very pertinent fact that while the bulk of the annual accumulation is laid down during the winter a very considerable redistribution of snow does take place during summer. As will be shown in a later section this mode of accumulation bears very critically on the formation of interpretable stratigraphy at the South Pole.

At the five stakes selected for the correlation studies the 47 -month accumulations were $77 \mathrm{~cm}$. at stake No. I0, $5^{8 \mathrm{~cm}}$. (No. 12), $87 \mathrm{~cm}$. (No. 20), IOI cm. (No. 28) and 7 I cm. at stake No. 35 respectively. These represent a reasonable spread of values with an average accumulation rate of about $7 \mathrm{~g} . \mathrm{cm}^{-2} \mathrm{yr}^{-1}$, in very close agreement with the average accumulation over the entire network. Vertical compaction of snow around the stakes must have caused some settling. However, the total displacement is probably quite small - of the order of $2-3 \mathrm{~cm}$. at most and it should be possible to compare the stake measurements and pit stratigraphy directly.

As clearly indicated in Figure 2 the summer stake measurements were found to correlate very closely with the occurrence of coarse-grained layers in the pits. The approximate positions of the late summer surfaces could be readily identified on the basis of grain structure alone. These surfaces were invariably associated with thin layers of depth hoar, generally overlain by an iced crust. Also, it would appear that not more than one thin layer of depth hoar is formed each year. Of particular interest in this respect was stake No. I0, where no accumulation was registered between 5 November $195^{8}$ and ro November 1959. This hiatus in the accumulation has left its imprint in the stratigraphy as an unusually thick $(4-5 \mathrm{~cm}$.) layer of very coarse and loosely packed grains at $50 \mathrm{~cm}$. depth. In addition, both the top and bottom surfaces of this layer of depth hoar were heavily crusted. Without the knowledge of stake measurements this layer of depth hoar would have been tied to a single accumulation year and observations in other pits indicate that abnormally thick layers of depth hoar can almost certainly be attributed to hiatuses of up to a year or more in accumulation. Hiatus-type depth hoar did not exceed $5 \mathrm{~cm}$. in thickness in any of the pits at the South Pole. However, at a 

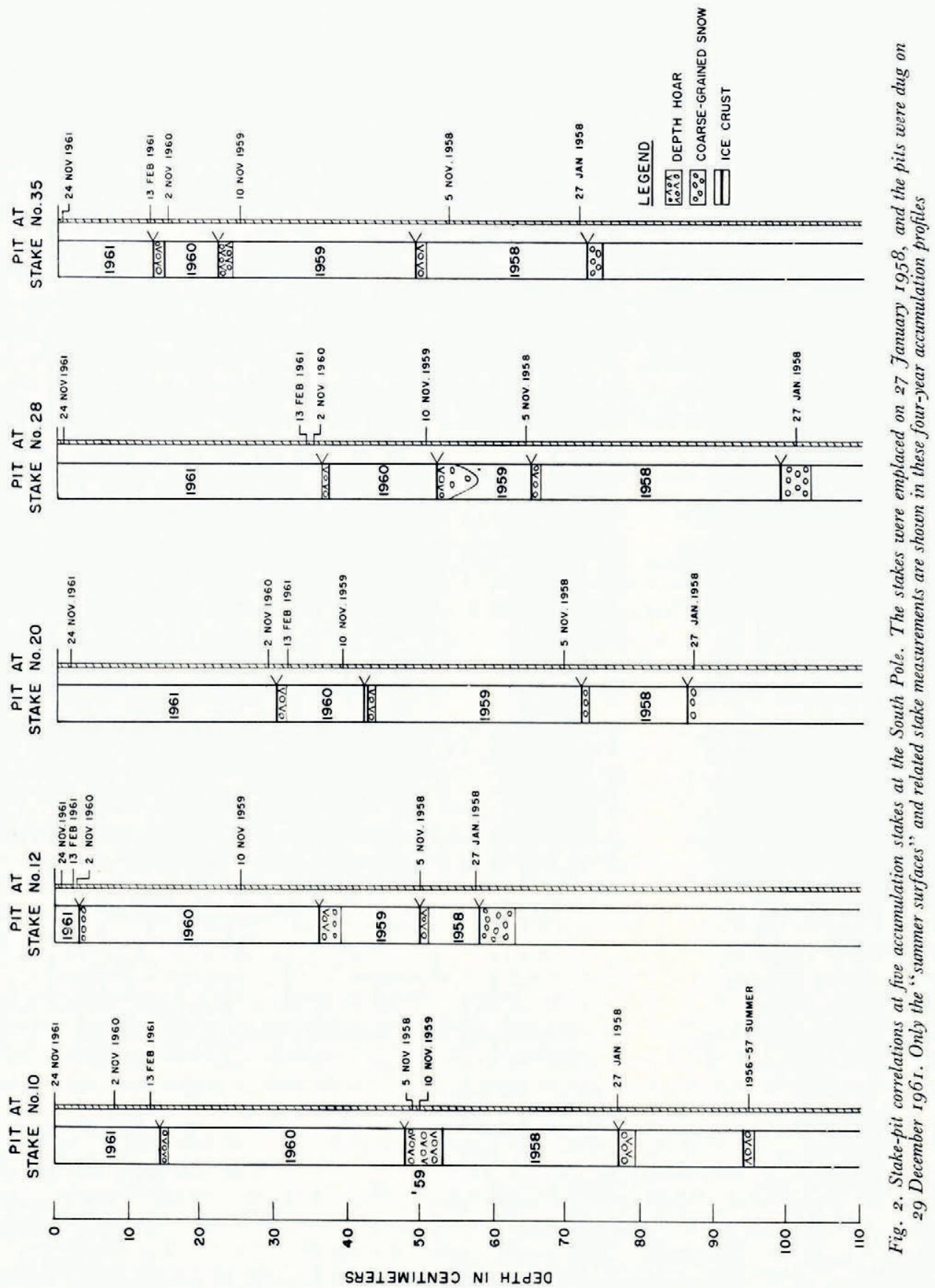
number of localities in Victoria Land, Antarctica, exceptionally thick layers of depth hoar up to $50 \mathrm{~cm}$. thick have been reported in pits by Giovinetto (I96I) and Stuart and Heine (196r). If the observations at the South Pole are any criterion then these unusually thick layers of depth hoar must be of multi-annual origin. At least we could suspect rather low rates of accumulation in those areas where such grossly sublimated snow has been encountered in pits, even in those pits where sublimation has tended to obliterate interpretable stratigraphy.

All pits at the South Pole possessed remarkably uniform stratigraphy. Some scour and redeposition, e.g. crossbedding, was detected in some layers, but such effects seldom hindered the identification of annual layering. At the South Pole then, the real problem of stratigraphic interpretation is concerned more with the recognition of hiatuses caused by a lack of accumulation than with hiatuses that supposedly result from wholesale erosion of snow layers at the surface. The relationship of non-accumulating surfaces to crusted or glazed surfaces was readily established by actual measurements at a number of stakes. Those which registered little or no accumulation between February i 96 I and November ig6i were all located near or upon glazed surfaces. Even the tracks of the vehicle used during measurements in February were still plainly visible on glazed surfaces when the stakes were revisited in November. These tracks invariably disappeared beneath the dunes and sastrugi that periodically intersected the glazed surfaces and which must have formed sometime in the interim. These dunes and sastrugi would appear to represent the great bulk of the accumulation of the winter of $196 \mathrm{r}$. It was also noted that glazed surfaces were most extensively developed on the crests of large surface undulations (wavelengths of several kilometers) that abound in the general area of the South Pole. Glazed surfaces may cover as much as 30-40 per cent of the total surface of a crest, and stake measurements show the crests to be areas of below-average accumulation. On the other hand, the troughs of these broad-scale undulations constituted areas of above-average accumulation, and glazed surfaces rarely exceeded ro per cent of the total snow surface. These undulations exert a very definite influence on rates of accumulation but a discussion of their origins is beyond the scope of this paper. However, it might be noted that these undulations are encountered over much of the surface of the Antarctic Ice Sheet and they certainly merit more detailed investigation.

In view of the very good correlations obtained in control pits at the South Pole, pits dug beside accumulation stakes should prove ideal sites for testing the reliability of the ${ }^{18} \mathrm{O} /{ }^{16} \mathrm{O}$ method of measuring accumulation rates in Antarctica. This method has been used very successfully in Greenland, (Benson, 1962) but the results so far from Antarctica have been somewhat contradictory. According to Epstein and others $\left(\mathrm{I}_{96}{ }_{3}\right)$ values derived from ${ }^{18} \mathrm{O} /{ }^{16} \mathrm{O}$ determinations give accumulation rates 20-100 per cent greater than those obtained from surface measurements and pit stratigraphy. Only in the deep pit at "Base Roi Baudouin" have the isotopic and stratigraphic methods checked reasonably well (Gonfiantini and others, I963). This agreement is attributable most probably to the large accumulation of $38 \mathrm{~cm}$. water equivalent annually, equivalent to more than a meter of snow. Here, as in Greenland, the seasonal precipitation probably has a much better chance of being preserved in situ than it does in the central regions of Antarctica where the annual accumulation rarely exceeds Io $\mathrm{cm}$. water. If isotopic methods are to prove at all reliable in deep cores, then they must first be proven reliable at locations where accumulation has been accurately measured at the surface for some years. Such control does exist at the South Pole. Accordingly, on 23 December 1963, two groups of samples were collected from pits dug beside two accumulation stakes. Approximately $\mathrm{I}$. $10 \mathrm{~m}$. snow had accumulated at each stake in six years. The samples are now being analyzed for both oxygen isotope and deuterium content. The walls of both pits were photographed for their stratigraphy and since these turned out much better than any obtained in the earlier studies, a complete photographic record of the stratigraphy at stake No. 25 is presented in Fig. 3. This profile shows just how sharply preserved the annual layers can be at the South Pole. 


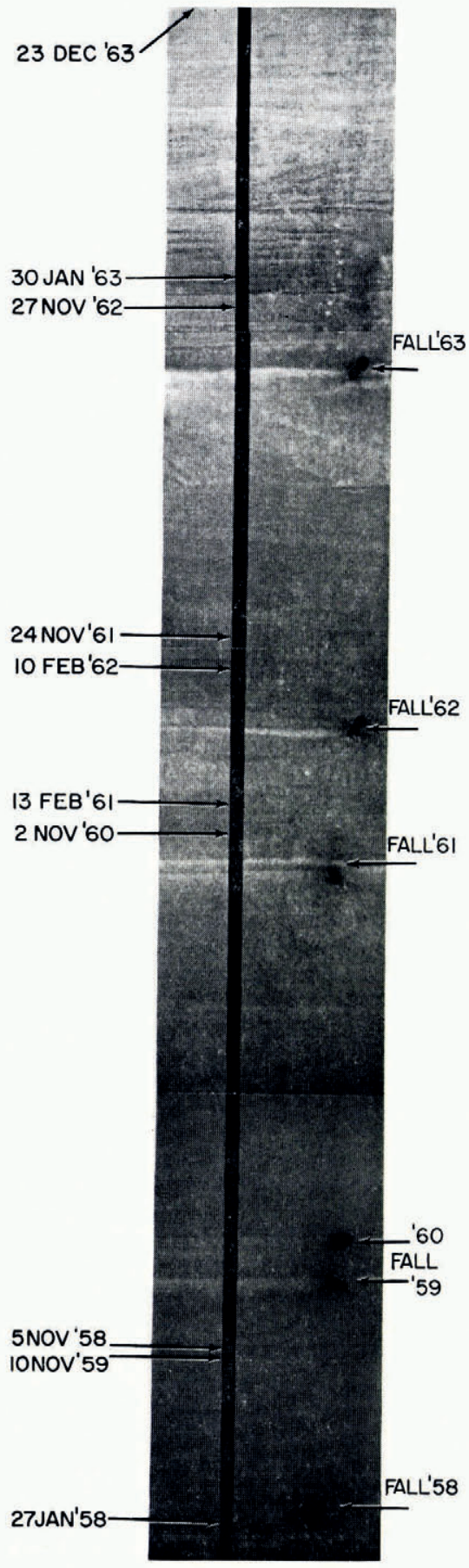

Fig. 3. Pholographic record of the stratigraphy in a pit used for collecting samples of snow for oxygen-isotope and deuterium analyses. Note the uniformity of the layering and occurrence of sharply delineated depth hoars (marked with pegs). The thickness of snow between two such layers of depth hoar represents a year's accumulation 


\section{Surface Relief}

At the end of winter the snow surface at the South Pole is characterized by extreme roughness and an abundance of large sastrugi. The scale of relief at this time of the year frequently exceeds the average thickness of snow accumulated annually. Because of this, there is a widespread belief that pit studies do not give reliable values of accumulation rates. However, it has been shown here from observations in pits dug beside accumulation stakes that this is not the case at all at the South Pole. Rarely, if ever, are the large-scale features of the surface relief preserved in the pit walls. It was of some interest then to observe a very considerable flattening of the surface relief during the $1960-6$ I summer. By mid-January I96I, even the largest sastrugi had been substantially reduced in size. The implication here is that it is this leveling of surface relief during the summer that has much to do with the formation of interpretable stratigraphy in snow pits at the South Pole. During the $196 \mathrm{I}-62$ summer these changes in surface relief were studied in somewhat greater detail. Though still largely qualitative, these observations show that the snow surface at the South Pole does pass through a definite cycle of events related closely to changes in the distribution of the annual increment of snow.

Surface relief at the South Pole includes a variety of features. While such forms as tiled and terraced sastrugi, deflation pockets, ripple marks and other small-scale features abound over much of the surface, the bulk of the relief is composed essentially of snow dunes and linear sastrugi (eroded snow dunes) interspersed with relatively flat patches of glazed surface (Fig. 4). The snow is not laid down as a uniform blanket, but accumulates instead in the form of well rounded "whaleback" dunes. These dunes, deposited during storms, can vary in length from a meter or so to many meters and are sometimes up to half a meter deep. Dunes can form at any time of the year but accumulation stake measurements for the past six years show that the bulk of the accumulation occurs during the autumn and winter at the South Pole. In the lulls between storms the dunes become consolidated by age-hardening. Once established, these

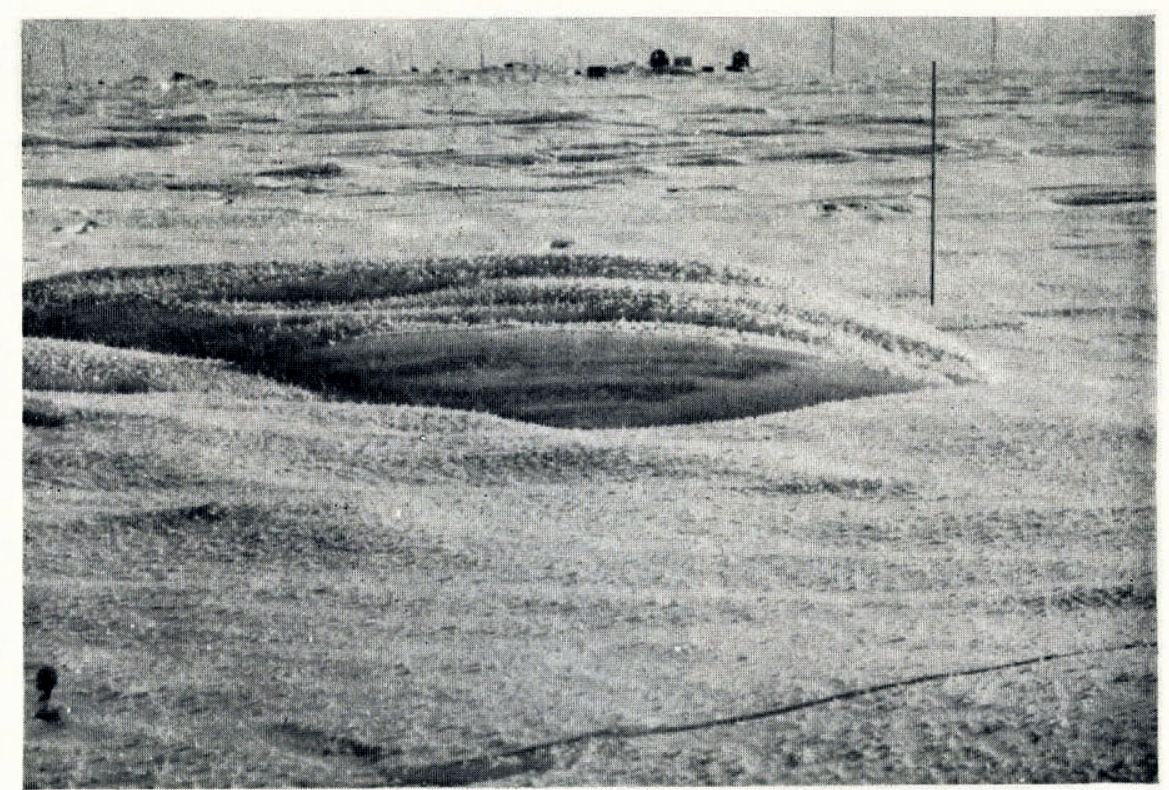

Fig. 4. Sublimating surface relief at the South Pole, showing dunes and linear sastrugi interspersed with patches of relatively flat accumulation-free surface. This photograph was taken in early December 196. . The large wind-dissected dune (linear sastruga) in foreground is about $4 \mathrm{~m}$. long and nearly $40 \mathrm{~cm}$. high. The prevailing wind direction is from the right and parallel to the long dimensions of the sastrugi 
dunes are no longer able to migrate bodily. The long axes of dunes are usually aligned in the direction of the prevailing wind (grid north-north-east). This coincidence of storm winds and prevailing surface winds imparts a strong grain to the surface relief which can be readily observed from the air. Throughout the winter the majority of snow dunes are eroded into elongate linear sastrugi by the abrasive action of wind-driven snow. Many of these sastrugi develop into forms that resemble upturned surfboards. The areas in between dunes may remain bare for months. With prolonged exposure to wind these surfaces become polished or glazed. Some of these surfaces may have originated as sun crusts during the preceding summer. Nevertheless, once formed, glazed surfaces are not particularly favorable to the retention of wind-blown snow, nor because of their relative hardness are they readily deflated. As already noted, observations at accumulation stakes show that such areas can remain free of snow for a year or longer. Tracks known to be at least a year old, even those produced by such a light conveyance as an akhio (boat-sled) have been seen at a number of places on glazed surfaces around the South Pole. When viewed in reflected sunlight a glazed surface can be detected quite readily on account of its puddle-like appearance, a characteristic that can be used to obtain quite reliable estimates of the ratio of accumulating to non-accumulating surfaces at any particular locality. This association of dunes (centers of accumulation) and glazed surfaces (accumulation-free areas) is a particularly significant one. Surfaces fated to become glazed generally do so because of a prolonged absence of accumulation. They should not be confused with true erosion surfaces that result from scouring of a pre-existing layer of snow. Nor by the same token, should the linear sastrugi be interpreted as the wind-chiseled remnants of the scoured layer. Instead we might consider the glazed surface as a plane of reference; initially a surface upon which snow is locally heaped into dunes but which in its accumulation-free areas between dunes has become glazed or polished through prolonged exposure to wind. A very similar situation has been reported by Stuart and Heine (196I) from low-accumulation areas in Victoria Land, Antarctica, where the year's accumulation occurs solely in the form of sastrugi superimposed on a hard surface.

At winter's end a surface of very considerable relief is exposed at the South Pole. The amplitude of this relief is determined essentially by the original dimensions of the dunes; the relative roughness of the surface will depend to a large extent on the number of dunes that have been eroded into sharp-edged sastrugi. However, such extreme relief does not endure through to the end of summer. Instead, it is gradually reduced by a rather interesting process that involves both sublimation and deflation of the surface snow. During December and January particularly, the dunes and sastrugi were observed to undergo a "softening-up" by sublimation of their flanks. The flanks are more susceptible to sublimation than the surrounding snow surface because of the much higher angle of incidence of the sun's radiation. This sublimation is readily revealed in the layers of scale-like crystals that form in situ from the surface layers of snow on the backs of the sastrugi and dunes (Fig. 5). Layers of crystals up to $2 \mathrm{~cm}$. thick can form in as little as three or four days during a spell of calm and relatively warm weather. This "loosening-up" of the structure of surface snow by sublimation alternates throughout the summer with periods of deflation, during which the very soft sublimation layers on the backs of dunes and sastrugi are stripped off by winds of even moderate intensity.

Occasionally during periods of still weather and clear skies, numerous spike-like crystals were observed adhering to the snow surface. These are clearly a form of hoar frost. Frost crystals appeared to grow more intensively on the dunes and sastrugi than elsewhere, suggesting perhaps, that some of this hoar frost might have formed by condensation of vapor originating in the dune itself. Hoar frost can only form during exceptionally calm weather. The crystals are attached so delicately to the surface that even the lightest winds will disperse them. Whether it represents a net loss or not, the amount of material undergoing sublimation at the South Pole appears to be substantially greater than is generally realized. Con- 
tinuation of the sublimation-deflation process throughout summer causes a gradual wearing down of the dunes and sastrugi and at the same time redistributes the snow more uniformly over the surface. It is unlikely that such a process is ever carried through to completion over the entire snow surface. However, the remarkably uniform and cyclical nature of stratigraphy in pits would imply that such a pattern of accumulation is effective over the greater part of the snow surface at the South Pole and that it does occur on an annually repeating basis.

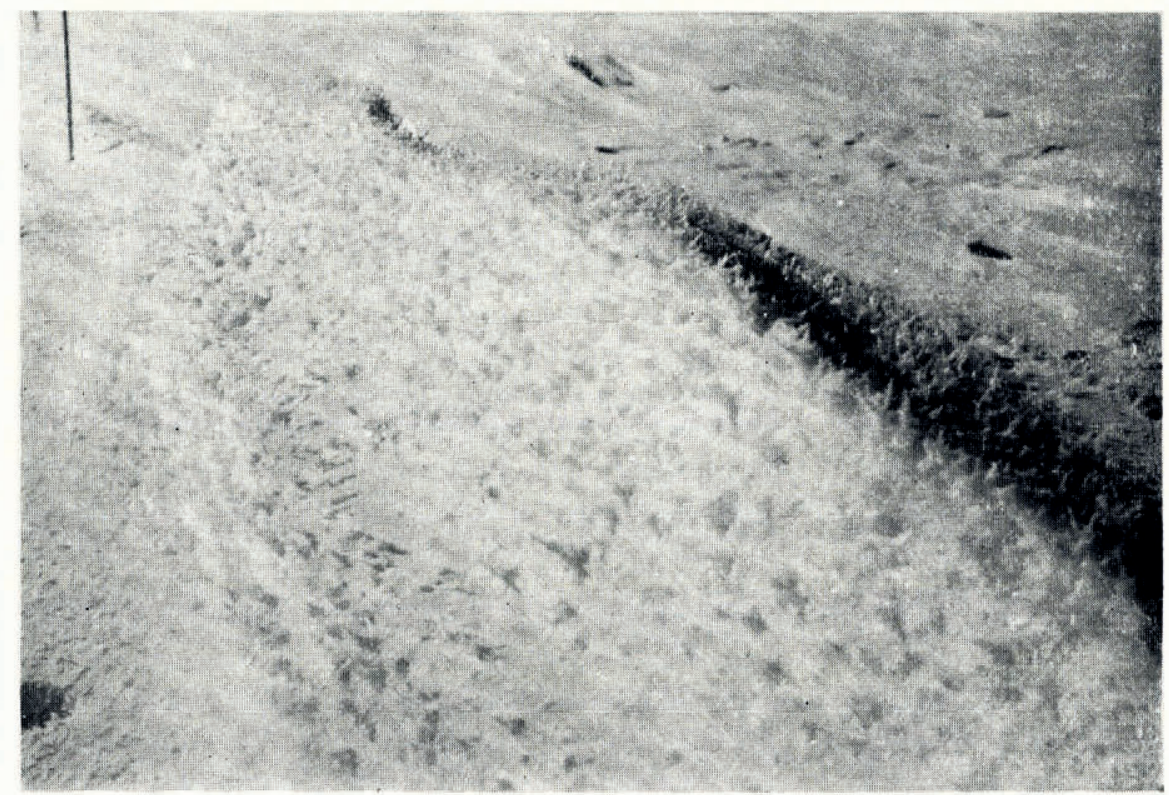

Fig. 5. Close-up view of a much sublimated sastruga with a layer of scale-like crystals forming on its flanks. Note also the growth of numerous spike-like crystals of hoar frost on parts of this sastruga and on the surrounding surface. This picture was taken in early January 1962

\section{Conclusion}

Detailed studies of the stratigraphy in a number of pits at the South Pole show that a careful count of the layers of depth hoar in the stratigraphic section yields thoroughly reliable records of past accumulation. Only a single layer of depth hoar up to $3 \mathrm{~cm}$. thick is formed each year. The formation of just one layer of depth hoar per year may well be unique at the South Pole where there is essentially one day and one night per year. The seasonal change is particularly abrupt from summer to winter and it is during this fall period that depth-hoar layers are formed at the South Pole. Somewhat thicker layers of depth hoar were observed beneath glazed surfaces. Such surfaces are known to originate in areas that can remain free of snow for a year or longer. When encountered in pits then, unusually thick layers of depth hoar (up to $5 \mathrm{~cm}$. thick) with strongly crusted upper surfaces can almost certainly be correlated with old accumulation-free areas.

An accretion of $20 \mathrm{~cm}$. snow annually, equivalent to $7 \mathrm{~g} . \mathrm{cm} \cdot .^{-2} \mathrm{yr}^{-1}$ can be considered a reliable value of the current rate of accumulation at the South Pole. The bulk of the annual accumulation is deposited during the winter. It is not deposited uniformly over the surface, but is locally heaped into dunes that are subsequently eroded into linear sastrugi. The amplitude of the resultant surface relief frequently exceeds the average thickness of snow accumulated annually, but such relief is rarely if ever preserved in the stratigraphy. The existence of 
generally uniform stratigraphy in pits of the South Pole can be attributed in large part to a gross leveling of this surface relief during the summer by process of sublimation-deflation. In this process the flanks of the dunes and sastrugi absorb more radiational heat than the surrounding snow surface. This results in the growth in situ on the backs of dunes and sastrugi of layers of loosely bonded crystals that are then removed at quite moderate wind speeds. The ultimate result is to redistribute the snow more uniformly over the surface. It is on this substantially level surface, evident at the end of summer, that the new year's accumulation will be deposited. In this sense then the stratigraphy at the South Pole can be said to reflect conditions of the surface at the end of summer rather than those at the end of winter.

\section{Acknowledgements}

This study was sponsored by the U.S. Antarctic Research Program and was financed in part by a grant from the National Science Foundation. Task Force 43 of the U.S. Navy provided invaluable support in the field. The assistance of these organizations is gratefully acknowledged. The author is indebted to Dr. Carl Benson (Geophysical Institute, University of Alaska) for his independent examination of two pits and subsequent discussion of the snow stratigraphy at the South Pole. Thanks are also due Dr. Benson and M. Giovinetto for their critical reviews of the manuscript.

$M S$. received 29 September 1964

\section{REFERENCES}

Benson, C. S. 1962. Stratigraphic studies in the snow and firn of the Greenland Ice Sheet. U.S. Snow, Ice and Permafrost Research Establishment. Research Report 70.

Epstein, S., and others. I 963 . Oxygen isotope ratios in Antarctic snow, firn, and ice, by S. Epstein, R. P. Sharp and I. Goddard. Journal of Geology, Vol. 71, No. 6, p. 698-720.

Giovinetto, M. B. I96o. Glaciology report for 1958, South Pole station. Ohio State University Research Foundation. Report $825^{-2}-$ Part IV.

Giovinetto, M. B. I96I. Mass accumulation in West Antarctica. Transactions. American Geophysical Union, Vol. 42, No. 3, p. 386-89; IGY Bulletin (Washington, D.C.), No. 5o, p. 6-9.

Gonfiantini, R., and others. I 963 . Snow stratigraphy and oxygen isotope variations in the glaciological pit of King Baudouin Station, Queen Maud Land, Antarctica, by R. Gonfiantini, V. Togliatti, E. Tongiorgi, W. de Breuck and E. Picciotto. Journal of Geophysical Research, Vol. 68, No. 13, p. 3791-98.

Gow, A. J., and Ramseier, R. O. 1963. Age hardening of snow at the South Pole. Journal of Glaciology, Vol. 4, No. 35 , p. $521-36$.

Stuart, A. W., and Heine, A. J. 1961. Glaciology, Victoria Land traverse, 1959-6o. Ohio State University Research Foundation. Report 968-1, p. 1-31. 